\title{
Penguraian Mekanisme Kerja Jamu Berdasarkan Jejaring Bahan Aktif-Protein Target-Gene Ontology
}

Penulis

Afiliasi
Vitri Aprilla Handayani ${ }^{{ }^{*}}$, Farit Mochamad Afendi ${ }^{2}$, Wisnu Ananta Kusuma ${ }^{3}$

${ }^{1}$ Pascasarjana Statistika Institut Pertanian Bogor (IPB), Indonesia

${ }^{2}$ Departemen Statistika, FMIPA, Institut Pertanian Bogor, Indonesia.

${ }^{3}$ Departemen IImu Komputer, FMIPA, Institut Pertanian Bogor, Indonesia

\section{Kata Kunci \\ $\rightarrow$ Diabetes Tipe II \\ $\rightarrow$ Fuzzy Clustering \\ $\rightarrow$ Graf Tri-Partite \\ $\odot$ Jamu}

Diterima 18 Agustus 2016 Direvisi 20 Septemebr 2016 Disetujui 30 Desember 2016

*Penulis korespondensi Vitri Aprilla Handayani Pascasarjana Institut Pertanian Bogor, Departemen Statistika Terapan , FMIPA, Kampus IPB Darmaga Bogor 16680 Email: vitriaprilla10@gmail.com

\section{ABSTRAK}

Jamu merupakan obat tradisional Indonesia. Pada dasarnya obat herbal yang dibuat dari bahan-bahan alami yang diambil dari beberapa bagian dari tanaman obat yang mengandung beberapa zat dan senyawa yang penting dan bermanfaat bagi tubuh. Sejauh ini, khasiat untuk beberapa jenis jamu secara empiris telah terbukti. Dalam peneitian ini, kami bermaksud untuk menguraikan mekanisme kerja jamu menggunakan pendekatan komputasi. Penelitian ini berfokus pada ramuan jamu type 2 diabetesyang terdiri dari empat tanaman, yaitu: jahe, bratawali, sembung, dan pare. Kerangka analisis awal dengan membentuk 3 komponen jejaring yang terdiri dari: (1) bahan aktif tanaman (diperoleh dari Knapsack: 58 senyawa aktif), (2) protein target (diperoeh dari database pubchem: 416 protein target), dan (3) gene ontoogy(diperoeh dari database DAVID: 3104 GO). Selanjutnya, kami menerapkan analisis klaster-klasterdengan menggunakan konsep graf tri-partite. Graf tri-partite digunakan untuk mengelompokkan komponen-komponen penyusun jejaring dari empat tanaman yang disebutkandiatas, sehingga diperoleh system bagian-bagian penyusun ramuan jamu. Hal ini dilakukan untuk mengungkapkan mekanisme kerja jamu. Menggunakan metode fuzzy clustering pada data jejaring, kami memperoleh 15 senyawa aktif yang diduga potensial sebagai antidiabetes berada dalam kelompok berbeda. Pada 15 senyawa aktif memiliki nilai peluang cukup tinggi terbagi dalam kelompok yang berbeda, setiap kelompok terdiri dari pasangan bahan aktif yang memiliki efek sinergis tinggi. Berdasarkan koneksi antara klaster-klasterprotein dan GO$\mathrm{BP}$, penelitianini memperoleh informasi protein-protein yang menyebabkan T2D dan mekanisme proses biologis yang terkait. T2D bukan hanya disebabkan oleh protein kelainan sekresi insulin (insulin-merendahkan enzim isoform 1) saja, tetapi juga disebabkan oleh protein lain yang terlibat dalam penghambatan insulin di pankreas.

\section{PENDAHULUAN}

Penyakit merupakan suatu keadaan tidak normal dari tubuh yang dapat menyebabkan kerusakan terhadap orang yang dipengaruhinya. Ada beberapa alternatif pengobatan yang dapat dilakukan seperti, pengobatan secara kimiawi dan pengobatan yang berbasis tanaman. Obat kimiawi biasanya hanya melibatkan satu senyawa kimia

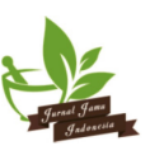


tunggal dengan satu target (one drug-one target), berbeda dari tanaman obat melibatkan banyak komponen senyawa kimia yang bekerja pada satu atau beberapa target (multicomponent-network target) (Zhang et al. 2013). Banyak jenis penyakit yang sering terjadi pada manusia. Penyakit metabolik degeneratif merupakan penyakit yang disebabkan oleh gangguan metabolisme tubuh akibat konsumsi berbagai jenis makanan instan yang tidak terkendali dengan proses degenerasi (Ndraha 2014).

Ada Beberapa jenis penyakit metabolik degeneratif antara lain diabetes militus type 2, stroke, hepatitis, cardiovascular, dan dyslipidemia (Umar 2007). Pada tahun 2012 diperkirakan penderita penyakit diabetes lebih dari 371 dan 90\% dari jumlah tersebut merupakan penderita diabetes type 2 (T2D). T2D merupakan suatu penyakit yang ditandai dengan tingkat glukosa darah tinggi, hal itu disebabkan insulin didalam tubuh lemah sehingga tidak dapat mengendalikan peredaran glukosa dengan baik, akibatnya tingkat glukosa dalam tubuh mengalami peningkatan. Hal itu dapat terjadi akibat pola hidup yang kurang teratur, usia, kehamilan dan berat badan yang berlebih (obesity) (Li et al. 2014).

Nurishmaya (2014) melakukan penelitian ramuan jamu untuk penyakit diabetes type 2 yang sedang dikembangkan pada Pusat Studi Biofarmaka di Bogor. Penelitiannya dicobakan pada ikan zebra sebagai hewan model yang diberikan perlakuan khusus. Ada empat tanaman yaitu pare (Momordica charantia), sembung (Blumea balsamifera), bratawali (Tinospora crispa), dan jahe (Zingiber officinale) diprediksi dapat mengobati T2D. Oleh sebab itu, akan dilakukan penelitian untuk meramu suatu jamu yang dapat mengobati T2D pada manusia. Pembuatan jamu yang melibatkan senyawa aktif tanaman, dapat dilakukan dengan pendekatan statistika yang dapat dimanfaatkan untuk mendapatkan senyawa aktif yang berperan mengobati suatu penyakit tertentu berdasarkan protein targetnya. Syahrir (2015) menggunakan metode NIMS (Network target-based Identification of Multicomponent Sinergy) untuk melihat efek sinergis antar kombinasi bahan aktif (skor sinergi), sehingga diperoleh pasangan bahan aktif antar tanaman sejenis maupun tanaman tidak sejenis. Hal itu ditunjukkan dari skor sinergi yang memiliki relatif tinggi. Metode NIMS merupakan salah satu usaha untuk mengetahui mekanisme kerja suatu ramuan jamu. Pasangan beberapa bahan aktif yang memiliki skor sinergi relatif tinggi dan signifikan adalah pasangan beberapa bahan aktif tanaman jahe dan pare, tanaman bratawali dan jahe, tanaman bratawali dan sembung, serta tanaman sembung dan jahe. Qomariasih (2015) melakukan suatu analisis data jejaring farmakologi (metode drugCIPHER) dilakukan untuk mencari protein-protein target yang memiliki korelasi terbesar dengan tiap senyawa. Metode drugCIPHER mampu mengubah kedekatan antara protein dan struktur kimia senyawa menjadi nilai numerik yang dapat dianalisis secara statistika dan komputasi. Terdapat 2 dari 3 senyawa bratawali dan 11 dari 44 senyawa jahe yang berpotensi sebagai obat antidiabetes. Sebaliknya tidak demikian untuk sembung dan pare, tetapi sembung dan pare berpotensi sebagai tanaman antidiabetes. James (2008), pankreas memiliki fungsi sebagai organ endokrin dan eksokrin. Fungsinya sebagai organ endokrin didukung oleh pulau-pulau Langerhans (Islets of Langeerhans) yang terdiri tiga jenis sel diantaranya, sel alfa $(\alpha)$ menghasilkan glukagon, sel beta $(\beta)$ menghasilkan insulin dan merupakan jenis sel pankreas paling banyak, sel delta (D) menghasilkan somatostatin. Kontrol utama pada sekresi insulin adalah sistem umpan balik negatif langsung antara sel $\beta$ di pankreas yang menghasilkan insulin dengan konsentrasi glukosa dalam darah. Peningkatan kadar glukosa darah, sepeti yang terjadi setelah proses pencernaan makanan secara langsung akan merangsang sintesa dan sekresi insulin oleh sel $\beta$ pankreas. Dengan adanya kadar insulin yang meningkat, maka akan menurunkan kadar glukosa darah ke tingkat yang normal karena terjadi peningkatan pemakaian dan penyimpanan glukosa.

Berdasarkan hasil penelitian diatas untuk mendapatkan suatu ramuan antidiabetes, akan ditelusuri proses biologi protein-protein yang ditargetkan oleh senyawa-senyawa yang terdapat dalam empat tanaman tersebut dan proses-proses yang terkait didalamnya. Gene ontology (GO) proses biologi merupakan suatu proses biologi protein-protein yang melibatkan beberapa gene didalamnya. Pengungkapan proses biologi ramuan jamu dilakukan dengan pendekatan komputasi berdasarkan bahan aktif, protein target, dan proses biologi. Dari empat tanaman yang diprediksi dapat mengobati T2D ditemukan sebanyak 416 protein unik yang berasal dari 58 bahan aktif yang memiliki target protein. Untuk mengetahui mekanisme kerja proses biologi tersebut dapat diterapkan metode statistika dengan pendekatan jejaring menggunakan graf tri-partite dan 
pengklasteran fuzzy. Penelitian ini bertujuan untuk menguraikan mekanisme kerja ramuan jamu, dan proses biologi protein yang ada didalam senyawa tanaman ramuan antidiabetes.

\section{METODE}

Data

Data yang digunakan dalam penelitian ini adalah data bahan aktif, protein target, dan GO dari tanaman obat yang sedang dikembangkan dalam Pusat Studi Biofarmaka, diprediksi mampu mengobati penyakit diabetes tipe 2 diantaranya: tanaman bratawali (Tinospora crispa), jahe (Zingiber officinale), pare (Momordica charantia), dan sembung (Blumea balsamifera). Ilustrasi struktur data ditunjukan pada Gambar 1 dan Tabel 1.

\section{Metode Analisis}

Mengidentifikasi GO-BP yang dimiliki oleh 416 protein unik menggunakan alat analisis dari sumber data DAVID, Identifikasi dilakukan pada Database David (https://david.ncifcrf.gov/), dengan menginput ID
(Entrez gene ID) yang dimiliki oleh 416 protein unik pada kolom yang disediakan di dalam DAVID Database (Huang et al. 2009).

Analisis mekanisme kerja jamu menggunakan fuzzy clustering graf tri-partite. Graf yang digunakan pada penelitian ini terdiri dari 3 komponen yaitu senyawa, protein dan GO (Gambar 1). Menurut Hartsperger et al. (2010) graf tri-partite yang dibentuk antara senyawa dan protein, protein dan GO proses biologi berupa data biner (0 dan 1). Pada analisis selanjutnya graf tri-partite yang dibentuk disebut sebagai matriks A. Suatu graf bernilai 1 jika memiliki koneksi antara senyawa dengan protein, maupun protein dengan $\mathrm{GO}$ proses biologi. Bernilai 0 jika tidak memiliki koneksi antara senyawa dengan protein, maupun protein dengan GO proses biologi. Selain itu, akan bernilai 0 ketika koneksi antara senyawa dan senyawa, protein dan protein, GO proses biologi dan $\mathrm{GO}$ proses biologi, serta senyawa dan $\mathrm{GO}$ proses biologi graf $G=(V, E)$, dimana $V=\{S 1, S 2, \ldots, S 58, P 1, P 2, \ldots$, P413, GO-BP1, GO-BP2, ...,GO-BP3104\}, dan $E$ merupakan koneksi antar S1, S2, ..., S58, P1, P2, ...,

Tabel 1. Jumlah bahan aktif dan protein

\begin{tabular}{lllll}
\multicolumn{1}{c}{ Tanaman } & & \multicolumn{1}{c}{ Senyawa } & \multicolumn{1}{c}{ Sumber } & \multicolumn{1}{c}{ Protein } \\
\hline Jahe & 47 & KNApSAcK & 2394 & Sumber \\
Pare & 4 & KNApSAcK & 47 & Pubchem \\
Sembung & 4 & KNApSAcK & 548 & Pubchem \\
Brotowali & 3 & KNApSAcK & 70 & Pubchem \\
\hline Total & $\mathbf{5 8}$ & & $\mathbf{3 0 5 9}$ & \\
\hline
\end{tabular}

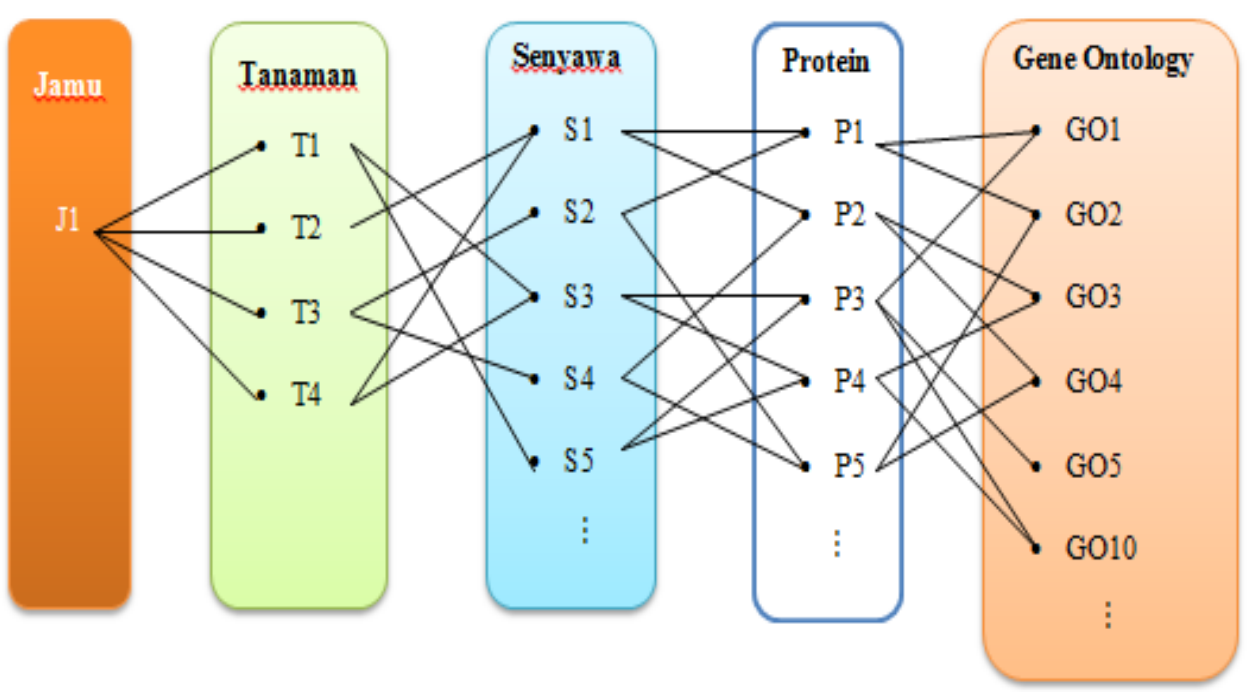

Gambar 1. Ilustrasi struktur data penelitian 
P413, GO-BP 1, GO-BP 2, ..,GO-BP

Langkah pertama yang dilakukan dalam melakukan analisis menggunakan klaster-pengklasteran fuzzy adalah membentuk matriks $\mathbf{A}$ yang terdiri dari 3 komponen yaitu: bahan aktif, protein target, dan GOBP. Kedua, menginisialisasi matriks $\mathbf{B}$ dan $\mathbf{C}$ secara acak yang berupa matriks non-negatif untuk melakukan iterasi selanjutnya $\boldsymbol{A}^{(i j)}=\boldsymbol{C}^{(i)} \boldsymbol{B}^{(i j)}\left(\boldsymbol{C}^{(j)}\right)^{T}$. Ketiga, melakukan iterasi untuk memperoleh matriks $\mathbf{B}$, dimana matriks B merupakan matriks yang elemenelemenya terdiri dari hasil pengklasteran pada matriks kedekatan A. Selanjutnya, melakukan iterasi untuk memperoleh matriks $\mathbf{C}$, matriks $\mathbf{C}$ merupakan matriks yang elemen-elemenya berupa peluang tiap node pada klaster tertentu. Pengiterasian matriks B dan C dilakukan sampai diperoleh hasil yang konvergen. Terakhir, mendekomposisikan matriks $\mathbf{B}$ dan $\mathbf{C}$ dengan menggunakan graf dengan pengklasteran fuzzy, sehingga diperoleh graf $H=(V, E)$ baru yang lebih sederhana, dan menguraikan proses biologi protein target yang terjadi melalui pengklasteran yang terbentuk.

\section{HASIL DAN PEMBAHASAN \\ Jejaring Farmakologi}

Jamu diabetes tipe 2 yang diprediksi terdiri dari empat tanaman yaitu, brotawali, jahe, pare, dan sembung memiliki senyawa sebanyak 58 senyawa dan protein target sebanyak 416 protein unik. Sedangkan, banyaknya koneksi antara senyawa dan protein ada sebanyak 3059 (Gambar 2).

Jejaring yang terbentuk pada Gambar 2 merupakan jejaring 58 bahan aktif yang dibentuk dari 4 tanaman bratawali sebanyak 3 bahan aktif (B013, B015, B018), pare sebanyak 4 bahan aktif (P044, P183, P185, P195), sembung sebanya 4 bahan aktif (S001, S002, S030, S031), dan 47 sisanya merupakan bahan aktif dari tanaman jahe. Tanaman bratawali memiliki koneksi ke protein target sebanyak 70 koneksi. Tanaman pare memiliki koneksi ke protein target sebanyak 47 koneksi. Tanaman sembung memiliki koneksi ke protein target sebanyak 544 koneksi. Tanaman jahe memiliki koneksi ke protein target sebanyak 2383 koneksi. Sebanyak 43 protein yang terlibat pada metabolisme sintesis insulin, atau terkait dengan pancreas yang terkait dengan diabetes tipe 2 .

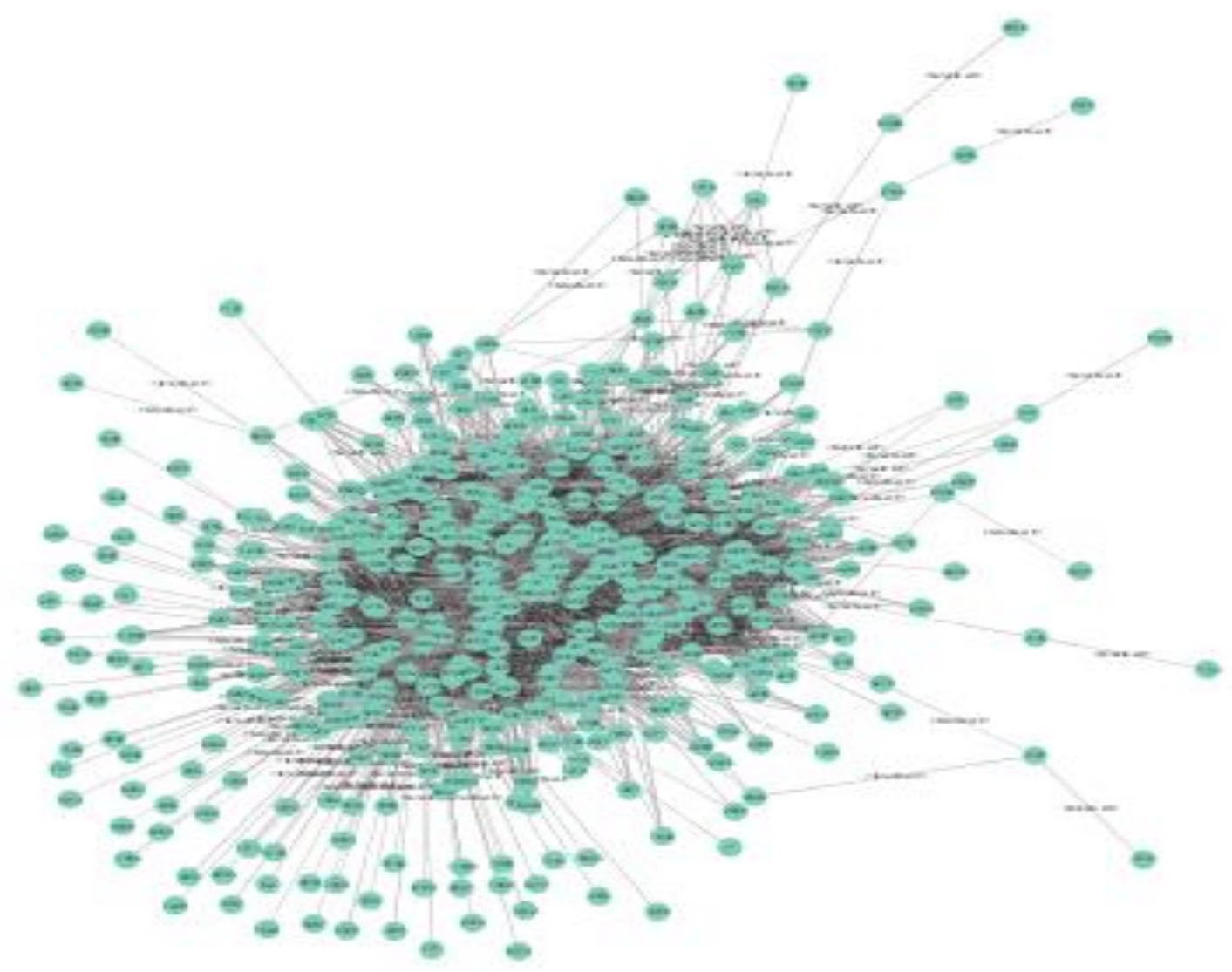

Gambar 2. Koneksi antara senyawa dan protein 
Masing-masing protein yang ditargetkan oleh senyawa tersebut memiliki mekanisme kerja yang terkait dengan proses biologi atau yang disebut Gene Ontology (GO) proses biologi. Dari 416 protein target yang dimiliki oleh 58 senyawa ditelusuri GO-BP signifikan yang terkait dengan proses biologi pada David database berdasarkan Entrez Gene-ID sebagai ID dari setiap protein. GO yang terseleksi pada DAVID Database merupakan GO BP paling relevan terkait dengan daftar gen tertentu. Kriteria GO yang signifikan pada David Database ( $p$-value $\leq 0.01$ dan EASE Score =0.06), diperoleh sebanyak 3104 GO dari David Database, koneksi antara protein dan GO-BP sebanyak 17626 (Gambar 3).

\section{Fuzzy clustering}

Pada penelitian ini metode yang digunakan untuk mengetahui seberapa besar peluang suatu objek masuk dalam klastertertentu adalah metode fuzzy clustering. Algoritma mendasar pada metode pengklasteran ini adalah penentuan jumlah klaster dan menghitung derajat keanggotaan (membership degree) yang dimiliki pada setiap objek. Pada penelitian ini derajat keanggotaan yang digunakan adalah graf tripartite yang dibentuk diatas. Prinsip dasar pengklasteran fuzzy adalah pengklasteran yang berbasiskan peluang, atau dengan kata lain besarnya peluang setiap objek untuk berada pada klaster tertentu antara 0 sampai 1 (Hartsperger et al. 2010).

\section{Penentuan jumlah klaster yang optimum}

Penentuan jumlah klaster dilakukan dengan cara mencari jumlah klaster yang optimum dengan melihat nilai Cost yang minimum pada setiap ulangan. Cost merupakan selisih minimum antara matriks $A$ dengan perkalian matriks $B$ dan $C$, atau dapat dituliskan sebagai $A^{(i j)}=C^{(i)} B^{(i j)}\left(C^{(j)}\right)^{T}$. Penentuan jumlah klaster yang optimum dilakukan dengan cara melakukan penentuan jumlah klaster dengan kombinasi 10 pengulangan pada setiap jumlah klaster $(2,3,4,5)$ sebanyak 640 ulangan. Jumlah klaster yang optimum dimiliki oleh jumlah klaster dengan nilai cost yang minimum. Selanjutnya, dilakukan analisis deskriptif nilai cost tersebut pada masing-masing kombinasi jumlah klaster senyawa, klaster protein dan klaster GO.

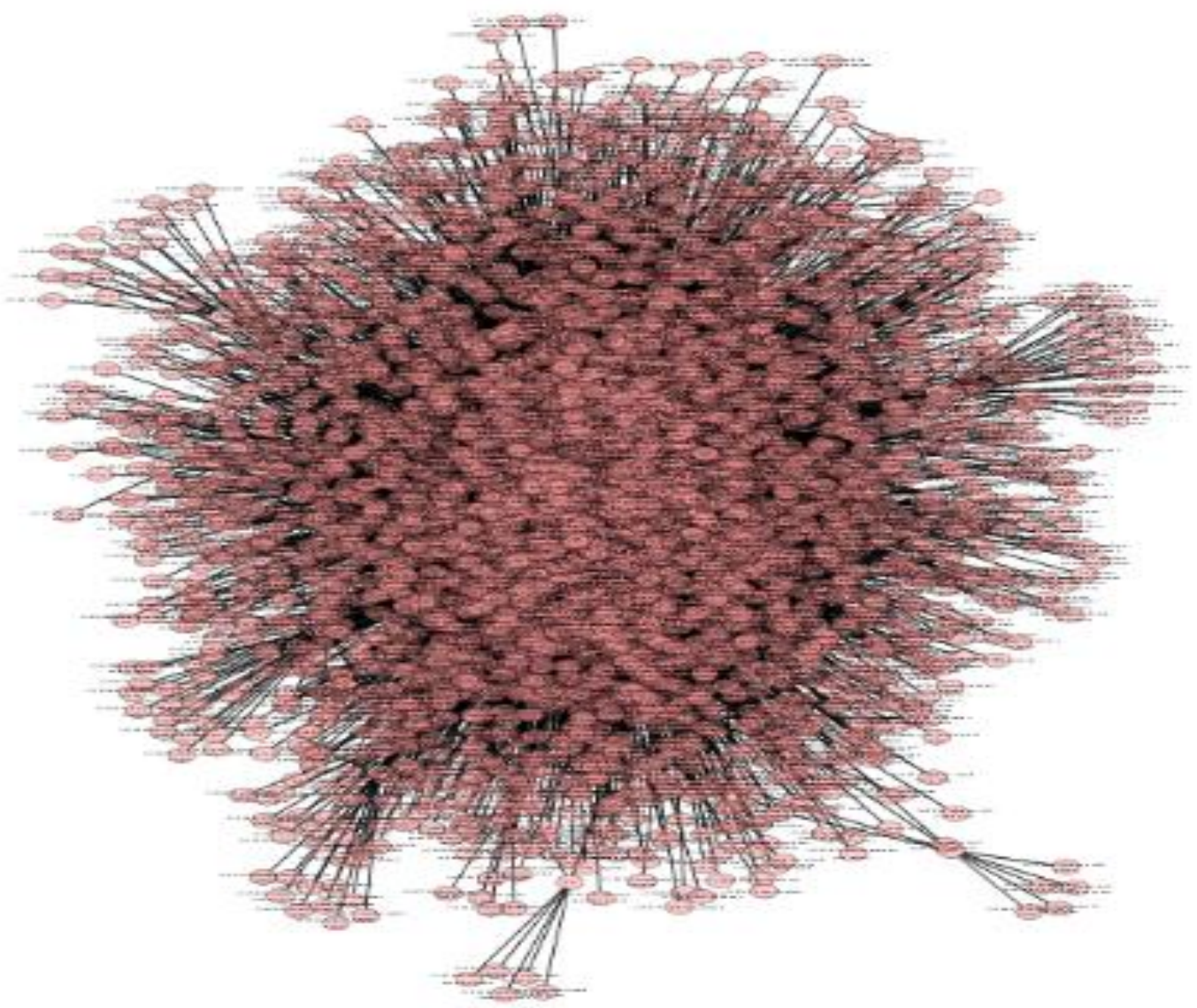

Gambar 3. Koneksi antara protein dan go proses biologi 
Pravitasari (2008), hasil analisis deskriptif nilai cost yang diperoleh bahwa pengujian masing-masing klaster signifikan pada $\alpha=5 \%$. Selanjutnya, penentuan jumlah klaster yang optimum pada masing-masing klaster senyawa, klaster protein, dan klaster GO dapat dilakukan dengan melihat pola penurunan nilai cost dibawah ini (Gambar 4).

Pada Gambar 4 terlihat bahwa jumlah klaster senyawa dan klaster protein sudah cukup konstan pada jumlah klaster 5 . Namun, untuk memastikan jumlah klaster senyawa dan klaster protein yang konsisten akan dilakukan pengklasteran pada jumlah yang lebih besar. Sedangkan, pola penurunan yang dimiliki oleh jumlah klaster GO sudah konsisten pada jumlah klaster 3-5. Sehingga akan diambil jumlah klaster untuk GO adalah sebanyak 4 klaster. Untuk memperoleh jumlah klaster yang optimum pada klaster senyawa dan klaster protein, maka dilakukan pengklasteran pada jumlah klaster yang lebih besar yaitu 6-10 klaster. Gambar 4b terlihat bahwa klaster senyawa sudah cukup optimum pada jumlah klaster 6-10, sehingga untuk klaster senyawa diambil sebanyak 6 klaster. Namun, untuk jumlah klaster protein 6-10 masih mengalami penurunan yang signifikan. Menurut Johnson dan

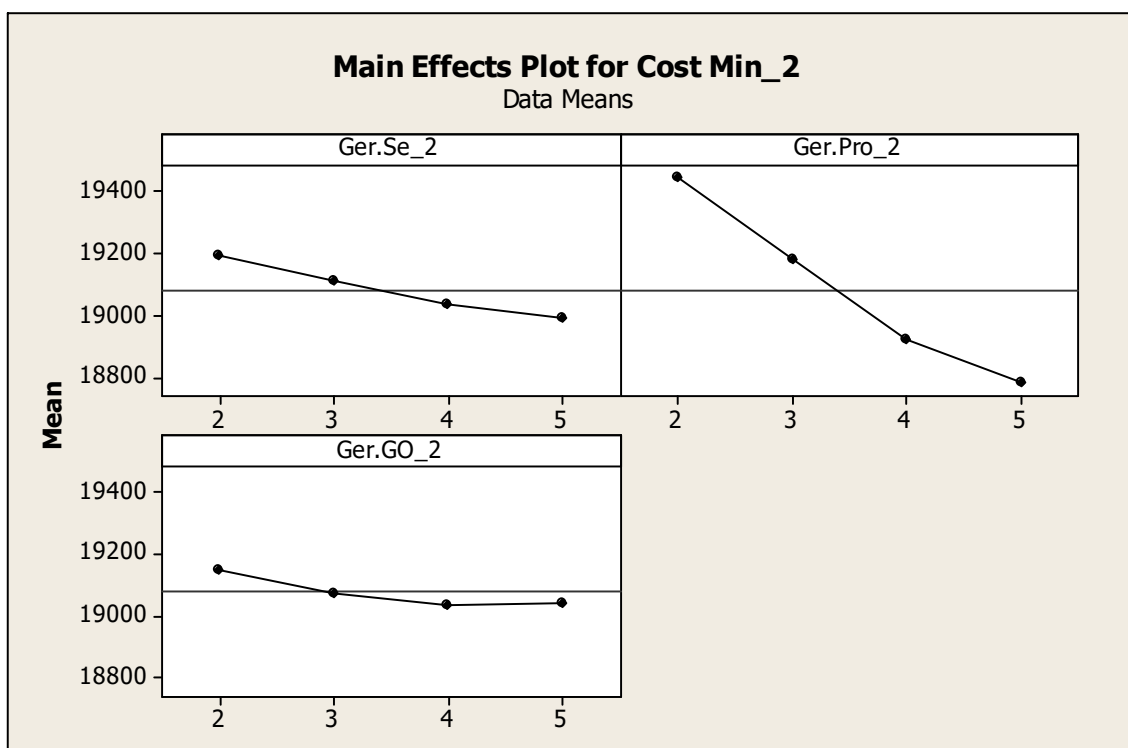

Gambar 4a. Pola penurunan nilai cost senyawa-protein-GO, kombinasi kluster 2-5

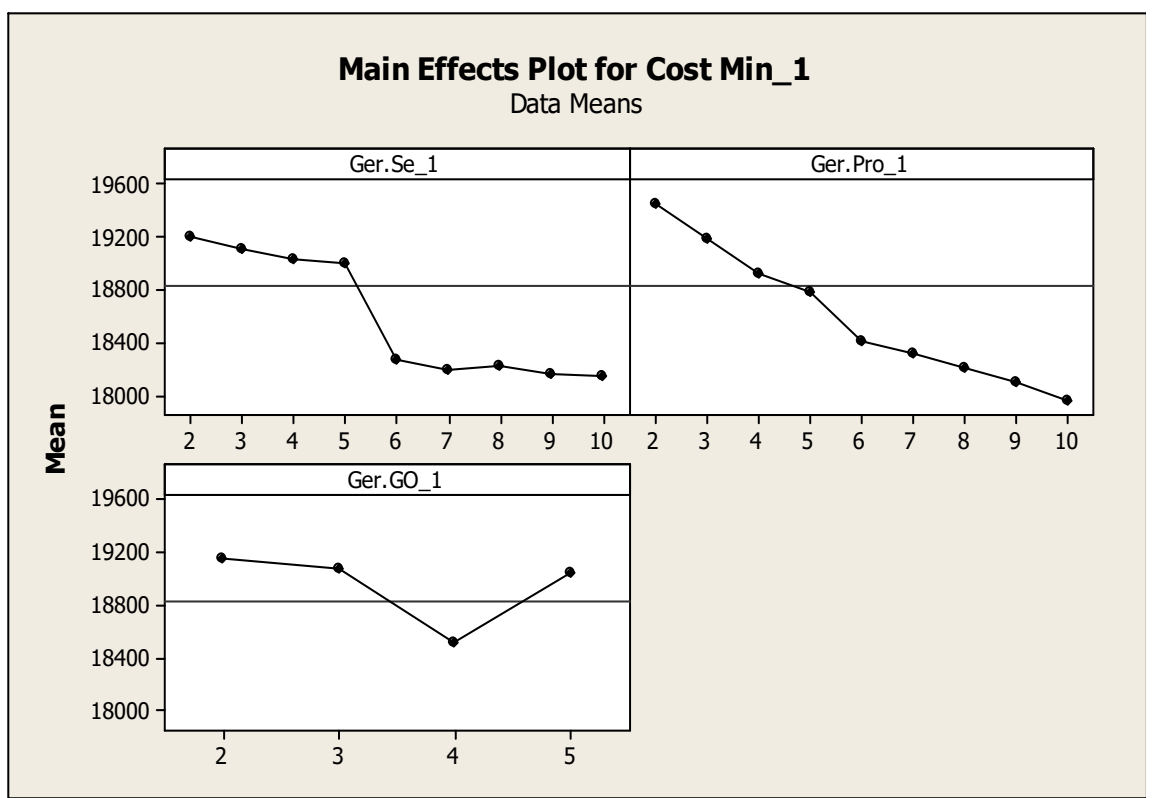

Gambar 4b. Pola penurunan nilai cost senyawa-protein-GO, kombinasi kluster 6-10 
Wichern (2002) semakin besar jumlah klaster, maka akan semakin kecil nilai akurasi yang dimiliki oleh suatu klaster. Sehingga, untuk mengefisiensikan jumlah klaster yang digunakan dalam pengklasteran tanaman obat dengan melihat pola penurunan nilai cost yang dimiliki pada masing-masing jumlah klaster senyawa, protein, dan GO adalah $[6,6,4]$.

\section{Fuzzy Clustering senyawa}

Pengklasteran pada 58 senyawa yang dimiliki oleh 4 tanaman obat yang diprediksi dapat mengobati diabetes tipe 2 akan diklasterkan sebanyak 6 klaster. Secara visualisasi bobot koneksi antar klaster yang diperoleh pada jejaring senyawa-protein dapat dilihat pada Gambar 5a. Qomariasih (2015), menggunakan metode pengklasteran simultan, plot PCA dan network similarity terdapat 15 senyawa aktif yang diprediksi sebagai komposisi utama ramuan jamu antidiabetes. Pada penelitian ini 15 senyawa aktif tersebut sebagian besar berada pada klaster 5. Namun, terdapat beberapa senyawa dengan peluang yang relatif tinggi berada pada klasteryang berbeda, yaitu: (B015) Ntrans-feruloyltyramine, (J207) borneol, dan (J218) (E,E)alpha-farnesene. Hal ini diduga bahwa ketiga senyawa tersebut merupakan senyawa pendukung dalam komposisi ramuan jamu T2D. Penelitian serupa juga dilakukan (Syahrir 2015) dengan menggunakan metode NIMS yang digunakan sebagai inisiasi awal untuk menduga efek sinergi antar pasangan senyawa aktif berdasarkan fenotipe penyakit, diperoleh beberapa

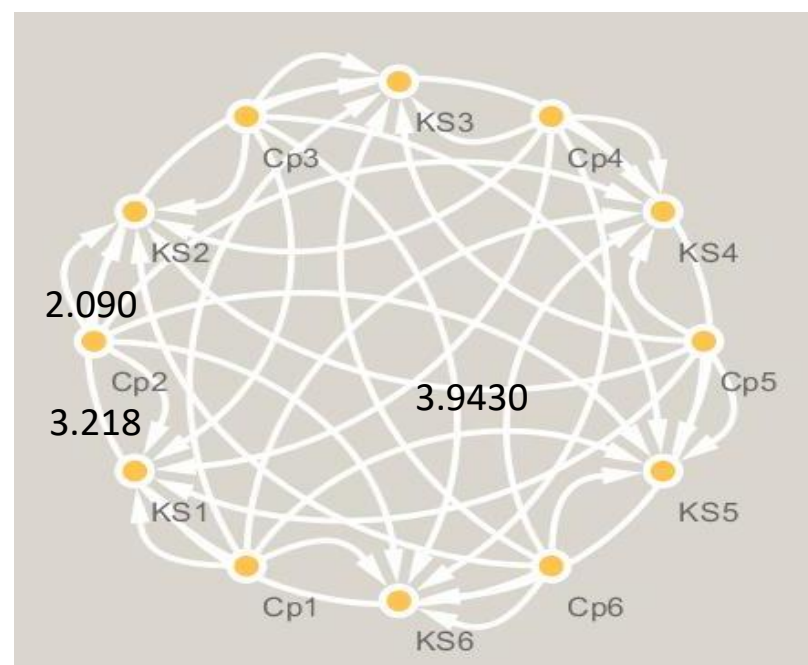

Gambar 5a. Dendogram fuzzy clustering senyawa, jejaring bobot koneksi senyawa-protein

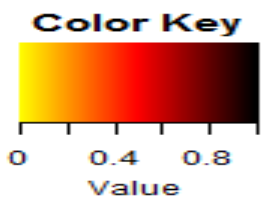

Senyawa

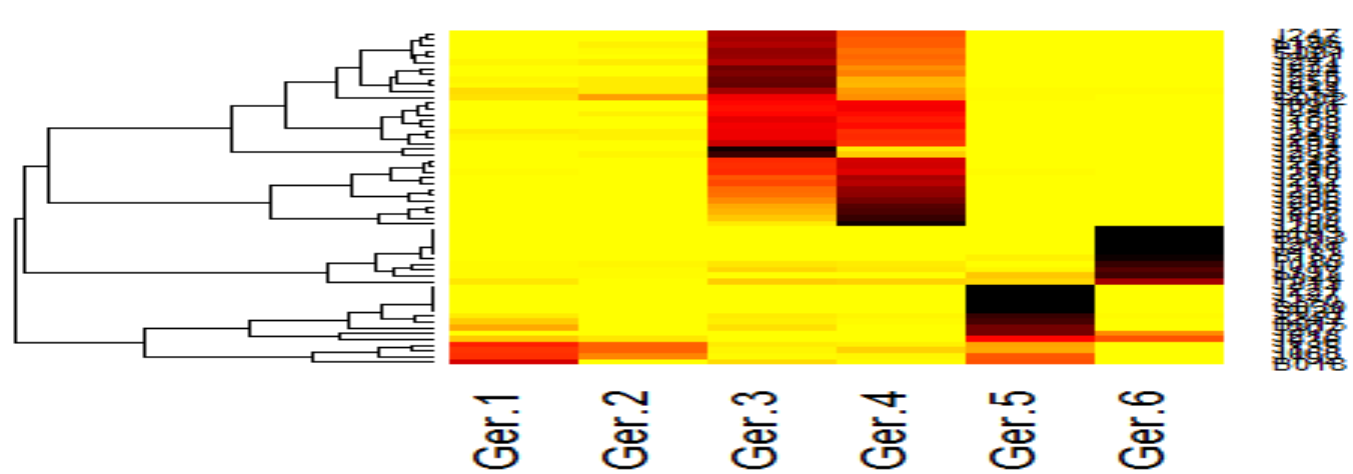

Gambar 5b. Dendogram fuzzy clustering senyawa, peluang senyawasenyawa-protein 
pasangan senyawa aktif dengan skor sinergi yang relatif tinggi antar tanaman yang berbeda. Namun, dengan menggunakan metode fuzzy clustering graf tri-partite, hanya sebagian pasangan bahan aktif yang memiliki skor sinergi relatif tinggi berpeluang besar berada pada satu klaster yang sama. Artinya, 15 senyawa aktif yang diprediksi sebagai komposisi utama ramuan jamu antidiabetes memiliki aktvitas yang berbeda, tetapi memiliki sasaran mengobati penyakit yang sama berdasarkan fenotipe penyakitnya.

\section{Fuzzy Clustering Protein}

Pengklasteran pada 416 protein unik yang ditargetkan oleh 58 senyawa sebanyak 6 klaster. Secara visualisasi pengklasteran yang diperoleh pada jejaring protein-GO dapat dilihat pada Gambar 6. Berdasarkan
Gambar 6a terlihat bahwa KP2 (klaster Protein ke-2) memiliki bobot yang cukup besar yaitu 0.7716 yang terkoneksi ke KGO4 (klaster GO ke-4), dan KP2 (klaster Protein ke-2) terkoneksi ke KGO2 (klaster GO ke-2) sebesar 0.4070, selain itu KP3 (klaster Protein ke-3) juga terkoneksi ke KGO2 (klaster GO ke-2) dengan bobot sebesar 0.2499 .

Pada hasil pengklasteran secara statistika (6b), protein yang diperoleh ada beberapa protein diantaranya yang terlibat dalam metabolisme sel $\alpha$, sel $\beta$ dan sel $D$ dalam produksi insulin dipankreas yaitu Alpha-2C adrenergic receptor berpeluang sebesar 0.99 berada pada klaster 1, Beta-1 adrenergic receptor berpeluang sebesar 0.96 berada pada klaster 1 , dan peroxisome proliferator-activated receptor delta yang berpeluang sebesar 0.95 berada pada gerobol 1 .

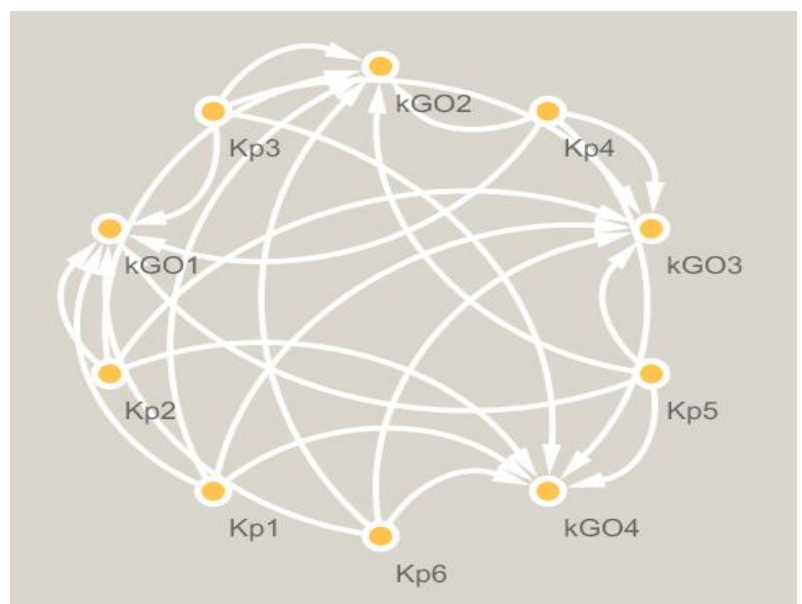

Gambar 6a. Histogram fuzzy clustering senyawa, jejaring bobot koneksi protein-GO proses biologi
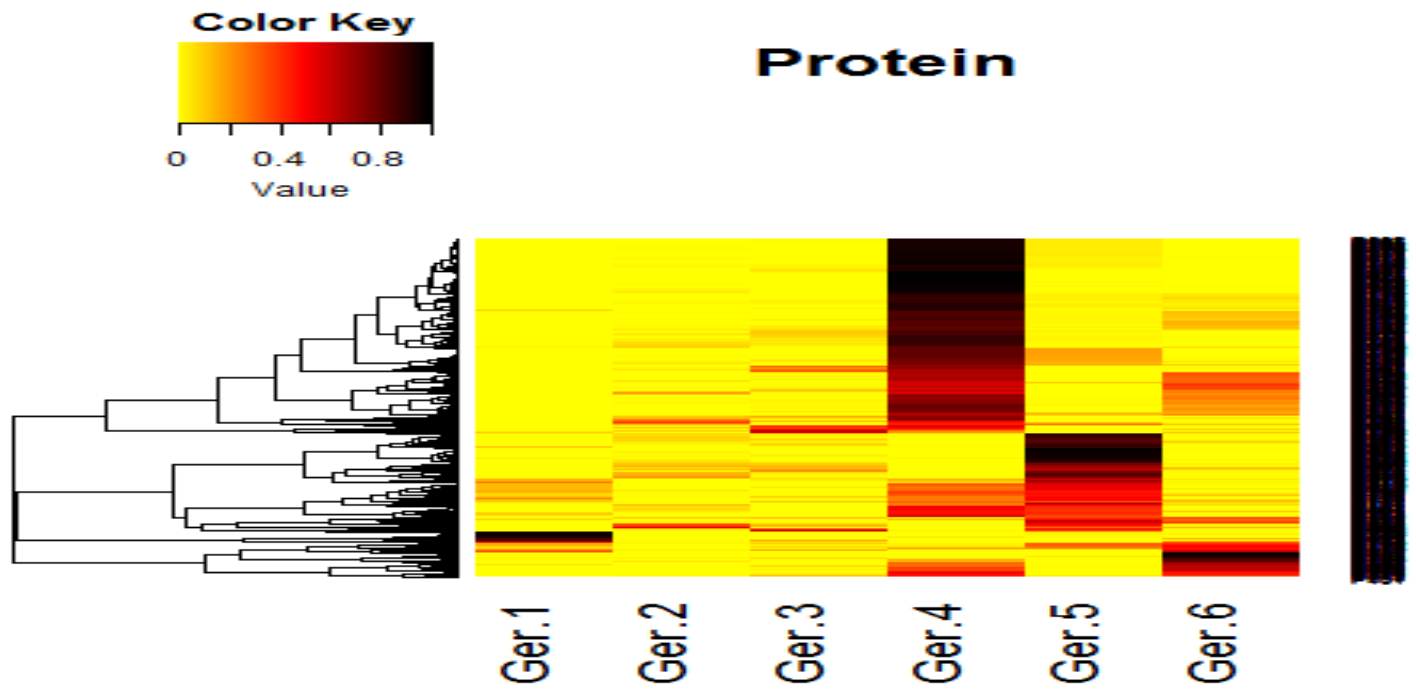

Gambar 6b. Histogram fuzzy clustering senyawa, dendogram peluang protein 
Sedangkan, untuk insulin-degrading enzyme isoform 1 merupakan protein yang sangat berperan dalam produksi insulin berpeluang sebesar 1.00 berada pada klaster 4 dengan protein-protein pendukung seperti phosphocholine phosphatase isoform1, alphagalactosidase dan protein lainnya yang berperan dalam produksi insulin.

\section{Fuzzy Clustering GO}

GO proses biologi signifikan yang pada DAVID Database diperoleh senbanyak 17626 GO yang terkoneksi dengan 416 protein target. Dari 17626 GO yang dimiliki oleh protein unik terdapat sebanyak 3104 GO unik. Selanjutnya, GO unik yang diperoleh akan digerombokan sebanyak 4 klaster (Gambar 7).

Pada penelitian ini (Gambar 7a) disebut sebagai matriks B. MatriksB merupakan jejaring bobot koneksi antaraklaster protein dan GO-BP. Terdapat 3 bobot koneksi yang cukup besar yaitu pertama, sebesar 0.7716 yang dimiliki antara GO-BP pada klaster ke-4 dan protein pada klaster ke-2. Kedua, sebesar 0.407 bobot yang dimiliki oleh GO-BP pada klaster ke-2 dan protein pada klaster ke-2. Ketiga, sebesar 0.2499 bobot yang dimiliki oleh GO-BP pada klaster ke-3 dan protein pada klaster ke-3. Namun, dari ketiga bobot koneksi yang cukup tinggi tersebut jika dikaitkan dengan hasil penggeromboalan pada protein yang berada pada klaster ke-1 merupakan proses biologi yang terlibat dalam proses metabolisme sel $\alpha$, sel $\beta$ dan sel $D$ dalam produksi insulin dipankreas meskipun banyak proses biologi lain yang terlibat didalamnya. selain itu, bobot koneksi yang dimiliki antara klaster-klaster GO-BP dengan protein pada klaster ke-4 seharusnya memiliki bobot koneksi yang besar, karena insulin-degrading

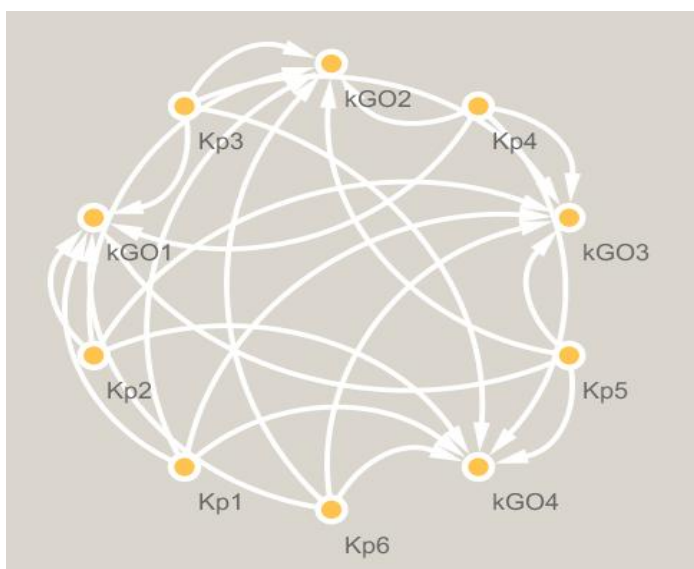

Gambar 7a. Dendogram fuzzy clustering GO-BP, jejaring bobot koneksi protein-GO proses biologi

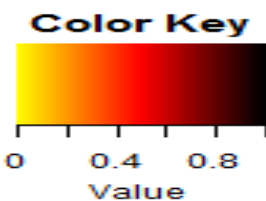

GO
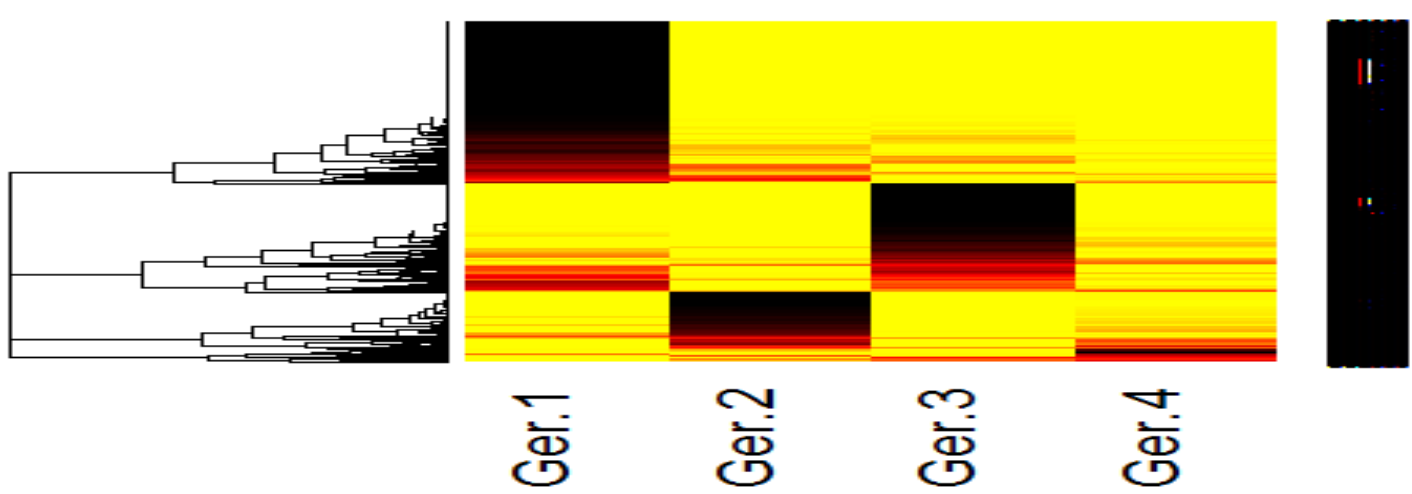

Gambar 7b. Dendogram fuzzy clustering GO-BP, dendogram fuzzy clustering GO-BP 
enzyme isoform 1 merupakan protein yang sangat berperan dalam produksi insulin berpeluang sebesar 1.00 berada pada klaster 4 .

Menurut (Vasamsetty et al. 2011), ada dua proses biologi yang terlibat dalam T2D. Pertama, proses biologi yang berkaitan dengan penurunan regulasi, kedua peningkatan regulasi T2D. Gene yang terlibat pada proses biologi dalam penurunan reguasi T2D yaitu: cell activation, macromolecule biosynthetic process, hydrogen peroxide biosynthetic process, immune response, dan regulation of glycolysis. Pada hasil dendogram fuzzy clustering $\mathrm{GO}$ proses biologi (7b), klaster 1 dan 3 sebagian besar merupakan genegene yang terlibat dalam proses biologi penurunan regulasi T2D. Sedangkan, gene yang terlibat dalam peningkatan regulasi T2D yaitu: aromatic compound biosynthetic process, nitric oxide biosynthetic process, dan regulation of glycolysis. Dari keseluruhan proses biologi yang terjadi pada 416 protein yang ditargetkan oeh 4 tanaman, terdapat 4 proses biologi yang terlibat dalam peningkatan regulasi terhadap T2D yaitu: GO:0006809 nitric oxide biosynthetic process, GO:0045019 negative regulation of nitric oxide biosynthetic process, GO:0045428 regulation of nitric oxide biosynthetic process, dan GO:0045429 positive regulation of nitric oxide biosynthetic process. Dari 4 proses biologi tersebut memiliki peluang yang cukup besar berada pada klaster 1 dan 3 .

\section{SIMPULAN}

Dari hasil pengklasteran senyawa, protein, dan GO-BP yang dilakukan menggunakan metode Fuzzy Clustering melalui graf tri-partite yang dibentuk diperoleh beberapa kesimpulan yaitu senyawa yang diprediksi sebagai komposisi utama ramuan jamu antidiabetes masing-masing memiliki aktivitas yang berbeda-beda berdasarkan fenotipenya dalam mengatasi penyakit, namun memiliki terget penyakit yang sama (T2D). Klaster-klaster pada protein yang ditargetkan oleh 58 senyawa memiliki peluang yang cukup besar untuk berada pada klaster tertentu yang terkait dengan protein penghambat metabolisme insulin yang menyebabkan T2D. Protein-protein pada klaster ke-1 yaitu alpha-2c adrenergic receptor, beta-1 adrenergic receptor, dan peroxisome proliferatoractivated receptor delta yang terilibat dengan penghambatan metabolisme insulin di pankreas. Sedangkan, proses biologi yang terkait dengan produksi insulin adalah protein insulin-degrading enzyme isoform 1 yang berada pada klaster ke-4 dengan protein-protein pendukung seperti phosphocholine phosphatase isoform1, alpha-galactosidase dan protein lainnya yang berperan dalam produksi insulin. Klaster 1 dan 3 hasil pengklasteran fuzzy clustering GO merupakan proses biologi yang terlibat dalam peningkatan dan penurunan regulasi T2D. Namun, hasil yang lebih dominan menunjukkan gene-gene yang terlibat dalam proses biologi penurunan regulasi T2D.

\section{DAFTAR PUSTAKA}

Hartsperger ML, Blochl F, Stumpflen V, Theis FJ. 2010. Structuring Heterogeneous Biological Information Using Fuzzy Clustering of K-Partite Graphs. BMC Bioinformatics. 11:522. 1-15.

Huang DW, Sherman BT, Lempicki RA. 2009. Systematic and integrative analysis of large gene lists using DAVID bioinformatics resources. Nature Protocol. 4(1):44-57.

James Norman MD. 2008. The Importance of Insulin and Glucagon. Diabetes and Hypoglicemia, Endocrine Web [Internet]. Tersedia pada: https://www.endocrineweb.com/conditions/di abetes/normal-regulation-blood-glucose.

Johnson RA, Wichern DW. 2002. Applied Multivariate Statistical Analysis, Fifth Edition. Englewood Cliffs (NJ): Prentice Hall.

Li H, Zhao L, Zhang B, Jiang Y, Wang X, Guo Y, Liu H, Li S, Tong X. 2014. A Network Pharmacology Approach to Determine Active Compounds and Action Mechanisms of Ge-Gen-Qin-Lian Decoction for Treatment of Type 2 Diabetes. Hindawi Publishing Corporation, Article ID 495840, 12 pages.

Mattjik AA, Sumertajaya IM. 2011. Sidik Peubah Ganda. Bogor (ID): Departemen Statistika, Institut Pertanian Bogor.

Ndraha S. 2014. Diabetes Melitus Tipe 2 dan Tatalaksana Terkini. Medicinus. 27(2):9-16.

Nurishmaya MR. 2014. Pendekatan Bioinformatika Formulasi Jamu Baru Berkhasiat Antidiabetes dengan Ikan Zebra (Danio rerio) Sebagai Hewan Model [Skripsi]. Bogor (ID): Institut Pertanian Bogor.

Pravitasari AA. 2008. Penentuan Banyak Kelompok dalam Fuzzy C-Means Cluster Berdasarkan Proporsi Eigen Value Dari Matriks Similarity dan Indeks XB (Xie dan Beni). Bandung (ID): Universitas Padjadjaran. 
Qomariasih N. 2015. Analisis Klaster Simultan dan Jejaring Farmakologi pada Penentuan Senyawa Aktif Jamu Anti Diabetes Tipe 2 [Tesis]. Bogor (ID): Institut Pertanian Bogor.

Syahrir NH. 2015. Uji Permutasi Efek Sinergis Bahan Aktif Tanaman Obat Berdasarkan Jejaring Dengan Protein Target [Tesis]. Bogor (ID): Institut Pertanian Bogor.

Umar HS. 2007. Indikator Gangguan Metabolik pada Penyakit Degeneratif. Makasar (ID): Departemen Penyakit Dalam Fakultas Kedokteran Universitas Hasanuddin.
Vasamsetty CS, Peri SR, Rao AA, Srinivas K, Someswara Rao C. 2011. Gene Expression Analysis for Type2 Diabetes Militus-A Study on Diabetes With and Without Parental History. Journal of Theoretical and Applied Information Technology. 27(1): 43-53.

Zhang GB, Li QY, Chen QL, Su SB. 2013. Network Pharmacology: A New Approach for Chinese Herbal Medicine Research. Hindawi. Article ID 621423, 1-9. 